\title{
Comparison of efficacy of Drotaverine hydrochloride and Valethamate bromide in the augmentation of labour: a hospital based randomized trial
}

\author{
Aparna Khan Mandal*, Nargis Molla
}

Department of Obstetrics and Gynecology, R. G. Kar Medical College, Kolkata, West Bengal, India

Received: 09 February 2018

Accepted: 07 March 2018

\section{*Correspondence:}

Dr. Aparna Khan Mandal,

E-mail: barapana.kol@gmail.com

Copyright: () the author(s), publisher and licensee Medip Academy. This is an open-access article distributed under the terms of the Creative Commons Attribution Non-Commercial License, which permits unrestricted non-commercial use, distribution, and reproduction in any medium, provided the original work is properly cited.

\begin{abstract}
Background: Labour is a process of contraction with the goal of producing progressive cervical effacement and dilatation in order to expel the uterine foetus from the intrauterine to the extra-uterine environment. The objective of this study was to compare the efficacy and safety of drotaverine hydrochloride and valethamate bromide for shortening the duration of labour.

Methods: This randomized trial was conducted at R. G. Kar Medical College over one year. Total 360 primigravida or multigravidae mothers satisfying the criteria of having singleton term pregnancy with cephalic presentation with spontaneous onset of labour were included and allocated randomly into Drotavarine Group (Group 1) and Valethamate Group (Group 2).

Results: There was statistically significant reduction of mean duration of first stage of labour both in primigravida $(123.12 \pm 37.82 \mathrm{~min}$ versus $156.30 \pm 45.10 \mathrm{~min})$ and multigravidae $(102.75 \pm 36.90 \mathrm{~min}$ versus $139.98 \pm 45.89 \mathrm{~min}) \mathrm{in}$ Group 1 than Group 2. P value $<0.0001$ in each Group. The mean rate of cervical dilatation in Group 1 was $3.0 \pm 0.41$ $\mathrm{cm} / \mathrm{hr}$ and $3.5 \pm 0.414 \mathrm{~cm} / \mathrm{hr}$ in primigravida and multigravidae respectively. $2.67 \pm 0.51 \mathrm{~cm} / \mathrm{hr}$ in primigravida and $2.90 \pm 0.44 \mathrm{~cm} / \mathrm{hr}$ in multigravidae in Group 2. It was statistically significant $(\mathrm{p}<0.0001$ in both Groups). Mean injection to delivery interval both in primigravida and multigravidae of Group 1 were significantly less than Group 2 $(\mathrm{p}=0.0006$ and $\mathrm{p}<0.0001$ respectively). Modes of delivery were comparable in both Groups ( $\mathrm{p}=0.756)$. Few maternal complications like transient tachycardia was more (12) in VB Group in compare to DH (3). Although it was not statistically significant $(\mathrm{p}=0.268)$. Foetal complications including Apgar score at $1 \mathrm{~min}$ and $5 \mathrm{~min}$ in both Groups were comparable in both primigravida and multigravidae ( $\mathrm{P}$ value 0.39718 and 0.285 respectively).

Conclusions: Drotaverine hydrochloride has promising beneficial effects on labour and it is safe to use.
\end{abstract}

Keywords: Drotaverine hydrochloride, Labour, Valethamate bromide

\section{INTRODUCTION}

Labour is a process of contraction with the goal of producing progressive cervical effacement and dilatation in order to expel the uterine foetus from the intrauterine to the extra-uterine environment. ${ }^{1}$ Labour mostly sets in spontaneously but for various obstetrical and medical indications it needs to be induced when the benefits to either the mother or the foetus outweigh those of continuing the pregnancy. ${ }^{2}$ Unduly prolonged labour is likely to give rise to 3 types of distress maternal, fetal or obstetrician and the last may be most dangerous. Prolonged and painful labour is not only a cause of mental anguish but also maternal and foetal morbidity 
and mortality due to increased risks of maternal exhaustion, postpartum haemorrhage and sepsis, fetal distress and asphyxia and requires early detection and appropriate clinical response. ${ }^{3}$ The risks for complications of prolonged labour are much greater in poor resource settings. ${ }^{4}$ Augmentation of labour is used to treat delayed labour when poor uterine contractions are the underlying cause. The traditional methods of labour augmentation is the use of oxytocin infusion and artificial rupture of the membranes (amniotomy). ${ }^{5}$ Over the last few decades, efforts to avoid prolonged labour in institutional birth have led to the use of a range of practices to either accelerate slow labour or drive the physiological process of normally progressing labour. While interventions with augmentation of labour may be beneficial, their inappropriate use can cause harm. Sedatives and belladonna alkaloids have been tried to hasten cervical dilatation, but many have adverse effects on mother and fetus. ${ }^{5}$ Spasmolytics and spasmoanalgesics mixtures are administered to facilitate dilatation of the cervix during delivery and to shorten first stage of labour. ${ }^{6}$ An ideal antispasmodic for accelerations of cervical dilations should have a prompt and long lasting action, no adverse effects on uterine contractility and be free from risk of uterine inertia. It should also have minimal side effects in the mother and foetus. ${ }^{5}$

Application of antispasmodics in obstetrics to relieve cervical spasm was first introduced by Von Kries and his pupils in 1923. Today the advent of various forms of pharmacological interventions have helped in shortening the duration of labour either by augmenting uterine contractions or by accelerating the rate of cervical dilatation. ${ }^{7}$ Drotaverine is an isoquinoline derivative which binds to the surface of smooth muscles and changes their membrane potential and permeability. It inhibits phosphodiesterase IV enzyme which breaks cAMP and cGMP which play an important role in regulation of smooth muscle tone. ${ }^{4}$ It acts specifically on spastic sites and corrects the cAMP and calcium imbalance relieving smooth muscle spasm. ${ }^{8}$ Valethamate bromide or epidosin is from the group of 'Efosin' described by Steinmann (1954) for use in hastening labour. ${ }^{9}$

It is an ester with quaternary $\mathrm{N}$ atom, which by virtue of its anticholinergic, parasympatholytics and musculotropic action relieves spasm of smooth muscle of cervix. These two drugs are used for cervical dilatation in modern obstetrics without deleterious effects on mother/fetus. ${ }^{8}$ In this era where the focus is shifting from 'wait and watch' policy to' active intervention sooner than later to ensure better labour outcomes, these drugs use in synergy with analgesics enable modern obstetricians to make labour and delivery a safe and pleasant experience for the mother.

The goal of the present study was to compare the efficacy and safety of drotaverine hydrochloride and valethamate bromide for shortening the duration of labour.

\section{METHODS}

The present study was conducted in the labour room complex in the department of Gynaecology and Obstetrics, R. G. Kar Medical College and Hospital from $1^{\text {st }}$ July 2014 to $30^{\text {th }}$ June 2015.

Present study was a prospective open-label randomized trial. Study population was drawn from antenatal mothers admitted to R. G. Kar Medical College and Hospital for delivery.

The study population comprised of two groups:

- Drotaverine hydrochloride group

- Valethamate bromide group.

\section{Study variables}

Independent variables

- Age

- Religion

- Socio-economic status

- Residence

- Gravid

Dependent variables

- Duration of $1^{\text {st }}$ stage of labour

- Injection to delivery interval

- Rate of cervical dilatation

- Number of injection required

- Rate of caesarean delivery

- Instrumental vaginal birth

- Dryness of mouth and vomiting

- Transient tachycardia

- Vomiting

- Retention of urine

- $\mathrm{PPH}$

- Postpartum fever

- Birth asphyxia

- Meconium aspiration syndrome

- $\quad$ APGAR Score at $1 \mathrm{~min}$. and $5 \mathrm{~min}$

- Neonatal sepsis

\section{Inclusion criteria}

- Live singleton pregnancy at term

- Both primigravida and multigravidae

- Cephalic presentation

- Spontaneous onset of labour

\section{Exclusion criteria}

- Ruptured membranes

- Cervical dilatation $>4 \mathrm{~cm}$ at admission

- Multiple gestation 
- Non-cephalic presentation

- Prior caesarean delivery

- Grand mulipara

- Cephalopelvic disproportion

- Previous h/o cervical surgery

- Preterm

- Hypertensive disorder

\section{Sample size}

A total of 360 women were randomized to drotaverine group and Valethamate group, 180 in each arm was needed to show a difference of 30 minutes mean injection delivery interval with use of injection drotaverine hydrochloride at $80 \%$ power and an alpha error 0.05 . With these assumptions in mind, we had taken 180 subjects per group which would be sufficient.

\section{Sampling design}

\section{Allocation}

Randomized randomization was performed by computergenerated random code, created in blocks of ten at R. G. KAR G and O office in Kolkata. The code was used by employee of our college who were not part of the research team as a basis for sealing cards in consecutively numbered envelopes; the cards read either "Drotaverine hydrochloride" or "Valethamate bromide". When a new participant was enrolled in the study, site staff opened the next envelope in the numbered series and the woman had received the treatment specified there in.

\section{End point classification}

- Safety

- Efficacy

- Acceptability

- Feasibility

Arms: Patient received injection drotaverine hydrochloride. Patient received injection Valethamate bromide.

\section{Masking: Open label}

\section{Method of data collection}

\section{Technique}

This study was done after getting approval from the Institutional ethics committee of our institution and it was conducted in the Department of Obstetrics and Gynaecology, R. G. Kar Medical College and Hospital. 360 women were selected for this study after an informed consent as per parameters cited above. Women who met the above requirements were given a full description of the study and asked if they would like to participate. Those who gave written informed consent were randomly assigned to one of the two study regimens. Women who were unable to read the consent form had the form read to them in their native language. Those who did not wish to participate were given standard treatment and care. 180 patients were allocated in each of the study groups.

\section{Group I}

Injection Valethamate was administered intravenously at an interval of 30 minutes, 1 hour up to a maximum of 6 injections.

\section{Group II}

Injection Drotaverine was administered intravenously during labour at an interval of 2 hours up to a maximum of 3 injections.

The patients were monitored for pulse rate, blood pressure, uterine contractions, progress and descent of presenting part, cervical dilatation and fetal heart sound. Maternal side effects like tachycardia, fever, dryness of mouth, nausea, vomiting was recorded.

Mode of delivery, duration of I, II, III stage of labour and fetal outcomes were recorded and compared to know the efficacy of Drotaverine and Valethamate on cervical dilatation and in shortening the duration of first stage of labour. Partograph was maintained during labour.

\section{Tools}

- Proper history taking and clinical examination

- Drugs: Drotaverine hydrochloride and Valethamate bromide

- CTG machine

- Syringe

- Thermometer

- USG facility-optional

\section{Laboratory investigations (not mandatory)}

- Routine hemogram

- Fasting blood sugar

- Post-prandial blood sugar

- Urine $\mathrm{R} / \mathrm{E}, \mathrm{C} / \mathrm{S}$

- Blood grouping and Rh typing

- HIV

\section{Definition of outcome}

\section{Injection to delivery interval}

Time interval between first injection to vaginal delivery.

\section{Duration of $1^{\text {st }}$ stage of labour}

Time interval between onset of true labour pain to full dilatation of cervix. 
Postpartum fever:

Oral temperature $>38^{\circ} \mathrm{C}$ on two separate occasions 6 hours apart after 24 hours of delivery.

\section{Rate of cervical dilatation}

It was monitored through partograph.

\section{Statistical analysis}

Data were analysed using SPSS statistical software (SPSS Inc., Chicago, IL, USA).

Chi-square tests were used for categorical data, and $\mathrm{z}$ tests were used for continuous data. Statistical significance in all calculations were defined as $\mathrm{P}<0.05$.

\section{RESULTS}

360 women were recruited for the trial, of which 180 mothers were recruited into Drotaverine group and 180 to Valethamate group. All the patients were available for data collection.

Table 1: Demographic profile.

\begin{tabular}{|c|c|c|c|}
\hline Age & \multicolumn{2}{|c|}{ No. of patients } & \multirow{5}{*}{$\begin{array}{l}x 2=1.93 \\
d f=2 \\
p=0.382\end{array}$} \\
\hline Age in years & DH & VB & \\
\hline$<20$ & $\begin{array}{l}15 \\
(8.34 \%)\end{array}$ & $\begin{array}{l}22 \\
(12.22 \%)\end{array}$ & \\
\hline $20-30$ & $\begin{array}{l}149 \\
(82.78 \%)\end{array}$ & $\begin{array}{l}146 \\
(81.11 \%)\end{array}$ & \\
\hline$>30$ & $\begin{array}{l}16 \\
(8.88 \%)\end{array}$ & $\begin{array}{l}12 \\
(6.67 \%)\end{array}$ & \\
\hline Religion & & & \\
\hline Hindu & $\begin{array}{l}73 \\
(40.56 \%)\end{array}$ & $\begin{array}{l}89 \\
(49.44 \%)\end{array}$ & $\mathrm{x} 2=2.87$ \\
\hline Muslim & $\begin{array}{l}107 \\
(59.44 \%)\end{array}$ & $\begin{array}{l}91 \\
(50.56 \%)\end{array}$ & $p=0.09$ \\
\hline Socio-econom & status & & \\
\hline Higher & $\begin{array}{l}5 \\
(2.78 \%)\end{array}$ & $\begin{array}{l}2 \\
(1.11 \%)\end{array}$ & \\
\hline Middle & $\begin{array}{l}61 \\
(33.89 \%)\end{array}$ & $\begin{array}{l}77 \\
(42.78 \%)\end{array}$ & $\begin{array}{l}\mathrm{x} 2=3.93, \\
\mathrm{df}=2,\end{array}$ \\
\hline Lower & $\begin{array}{l}114 \\
(63.33 \%)\end{array}$ & $\begin{array}{l}101 \\
(56.11 \%)\end{array}$ & $p=0.140$ \\
\hline Residence & & & \\
\hline Rural & $\begin{array}{l}127 \\
(70.56 \%)\end{array}$ & $\begin{array}{l}141 \\
(78.33 \%)\end{array}$ & $\mathrm{x} 2=2.86$, \\
\hline Urban & $\begin{array}{l}53 \\
(29.44 \%)\end{array}$ & $\begin{array}{l}39 \\
(21.67 \%)\end{array}$ & $\begin{array}{l}\mathrm{dt}=1 \\
\mathrm{p}=0.091\end{array}$ \\
\hline Gravida & & & \\
\hline Primigravida & $\begin{array}{l}112 \\
(62.22 \%)\end{array}$ & $\begin{array}{l}122 \\
(67.78 \%)\end{array}$ & $\mathrm{x} 2=1.22$ \\
\hline Multigravidae & $\begin{array}{l}68 \\
(37.78 \%)\end{array}$ & $\begin{array}{l}58 \\
(32.22 \%)\end{array}$ & $p=0.269$ \\
\hline
\end{tabular}

We have enrolled 360 mothers, 180 mothers in each group. Drotaverine hydrochloride and Valethamate bromide.

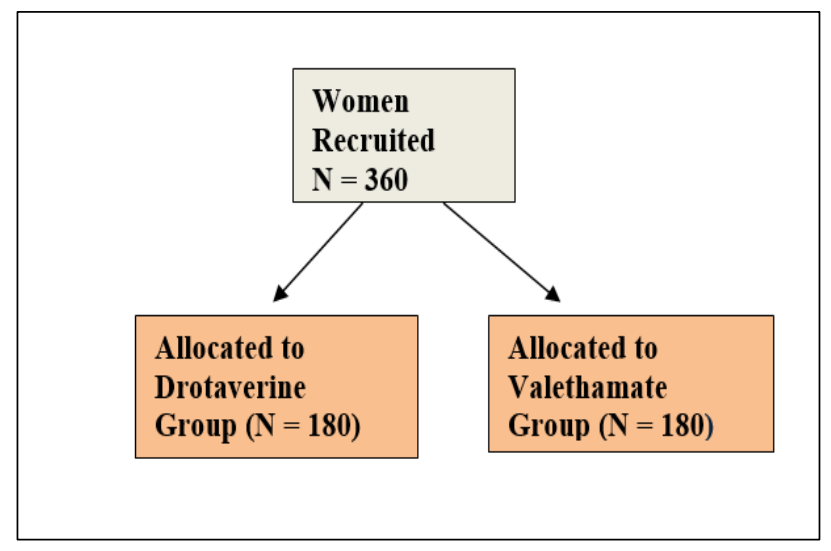

Figure 1: Consort flow chart.

Demographic profile and clinical parameters in all the patients were comparable at the start of study. There were no statistically significant differences.

Table 2: Labour outcomes.

\begin{tabular}{|c|c|c|c|}
\hline & $\begin{array}{l}\text { Drotaverine } \\
\text { Hydrochloride }\end{array}$ & \multicolumn{2}{|l|}{$\begin{array}{l}\text { Valethamate } \\
\text { Bromide }\end{array}$} \\
\hline \multicolumn{4}{|c|}{ Duration of active phase of labour in primigravida } \\
\hline$<2$ hours & $52(46.42 \%)$ & $31(25.40 \%)$ & \multirow{3}{*}{$\begin{array}{l}P= \\
0.0001\end{array}$} \\
\hline 2-3 hours & $53(47.32 \%)$ & $52(46.42 \%)$ & \\
\hline$>3$ hours & $07(6.25 \%)$ & $39(34.82 \%)$ & \\
\hline $\begin{array}{l}\text { Mean of } \\
\text { duration of } \\
1^{\text {st }} \text { stage of } \\
\text { labour }\end{array}$ & $123.12 \pm 37.82$ & $156.30 \pm 45.10$ & $\begin{array}{l}P \text { value } \\
<0.0001\end{array}$ \\
\hline \multicolumn{4}{|c|}{ Duration of active phase of labour in multigravidae } \\
\hline$<2$ hours & $39(57.35 \%)$ & $22(37.93 \%)$ & \multirow{3}{*}{$\begin{array}{l}P=0.000 \\
1\end{array}$} \\
\hline 2-3hours & $29(42.65 \%)$ & $23(39.66 \%)$ & \\
\hline$>3$ hours & 0 & $13(22.41 \%)$ & \\
\hline $\begin{array}{l}\text { Mean of } \\
\text { duration of } \\
1^{\text {st }} \text { stage of } \\
\text { labour }\end{array}$ & $\begin{array}{l}102.75 \pm 36.9 \\
\min \end{array}$ & $\begin{array}{l}139.98 \pm 45.89 \mathrm{mi} \\
\mathrm{n}\end{array}$ & $\begin{array}{l}P \text { value } \\
<0.0001\end{array}$ \\
\hline \multicolumn{4}{|c|}{ Mean rate of cervical dilatation $(\mathrm{cm} / \mathrm{hr})$} \\
\hline Primigravida & $3.0 \pm 0.41$ & $2.67 \pm 0.51$ & $\begin{array}{l}P \text { value } \\
<0.0001\end{array}$ \\
\hline Multigravida€ & $3.5 \pm 0.414$ & $2.90 \pm 0.44$ & $\begin{array}{l}\mathrm{P} \text { value } \\
<0.0001\end{array}$ \\
\hline \multicolumn{4}{|c|}{ Mean injection to delivery interval } \\
\hline Primigravida & $\begin{array}{l}190.92 \pm 38.96 \mathrm{mi} \\
\mathrm{n}\end{array}$ & $\begin{array}{l}209.80 \pm 45.13 \mathrm{mi} \\
\mathrm{n}\end{array}$ & $\begin{array}{l}\text { P value } \\
0.0006\end{array}$ \\
\hline Multigravida€ & $\begin{array}{l}132.08 \pm 32.99 \mathrm{mi} \\
\mathrm{n}\end{array}$ & $\begin{array}{l}172.86 \pm 48.35 \mathrm{mi} \\
\mathrm{n}\end{array}$ & $\begin{array}{l}\mathrm{P} \text { value } \\
<0.0001\end{array}$ \\
\hline \multicolumn{4}{|c|}{ Mode of delivery } \\
\hline $\begin{array}{l}\text { Spontaneou } \\
\text { s vaginal } \\
\text { delivery }\end{array}$ & $165(91.67 \%)$ & $161(89.44 \%)$ & \multirow{3}{*}{$\begin{array}{l}x 2= \\
0.55, \mathrm{df} \\
=2, \mathrm{P}= \\
0.756\end{array}$} \\
\hline Instrumental & $2(1.11 \%)$ & $3(1.6 \%)$ & \\
\hline LSCS & $13(7.22 \%)$ & $16(8.89 \%)$ & \\
\hline
\end{tabular}


Mean duration of $1^{\text {st }}$ stage of labour was $123.12 \pm 37.82$ $\min$ and $156.30 \pm 45.10 \mathrm{~min}$ in primigravida and $102.75 \pm 36.90 \mathrm{~min}$ and $139.98 \pm 45.89 \mathrm{~min}$ in multigravidae in Drotavarine and Valethamate groups respectively. $\mathrm{P}$ value $<0.0001$ in both cases.

Mean rate of cervical dilatation in primigravidae 3.0 \pm 0.41 $\mathrm{cm} / \mathrm{hr}$ and $3.5 \pm 0.414 \mathrm{~cm} / \mathrm{hr}$ in multigravidae in $\mathrm{DH}$ and $2.67 \pm 0.51 \mathrm{~cm} / \mathrm{hr}$ and $2.9 \pm 0.44 \mathrm{~cm} / \mathrm{hr}$ in primigravida and multigravidae in VB group respectively.

The results are statistically significant $(\mathrm{p}<0.05)$. Mean injection to delivery interval was less both for primigravida and multigravidae in $\mathrm{DH}$ group than $\mathrm{VB}$ group $(190.92 \pm 38.96 \mathrm{~min} \mathrm{v} / \mathrm{s} \quad 209.80 \pm 45.13 \mathrm{~min}$ in primigravidae and $132.08 \pm 32.99 \mathrm{~min} \mathrm{v} / \mathrm{s} 172.86 \pm 48.35$ min in multigravidae). Mode of delivery was comparable in both groups $\mathrm{P}=0.756$.

Table 3: Foeto-maternal outcomes.

\begin{tabular}{|c|c|c|c|c|c|}
\hline \multicolumn{6}{|c|}{ Maternal complications } \\
\hline \multirow{2}{*}{ Complications } & \multicolumn{4}{|c|}{ No. of patients } & \multirow{14}{*}{$\begin{array}{l}x 2=21.2 \\
d f=18 \\
p=0.268\end{array}$} \\
\hline & DP & $\mathbf{V P}$ & DM & VM & \\
\hline Vomiting & 7 & 5 & 3 & 3 & \\
\hline $\begin{array}{l}\text { Dryness of } \\
\text { mouth }\end{array}$ & 0 & 3 & 0 & 2 & \\
\hline $\begin{array}{l}\text { Transient } \\
\text { tachycardia }\end{array}$ & 3 & 12 & 4 & 9 & \\
\hline $\begin{array}{l}\text { Retention of } \\
\text { urine }\end{array}$ & 0 & 1 & 0 & 0 & \\
\hline $\begin{array}{l}\text { Cervical } \\
\text { tear }\end{array}$ & 1 & 1 & 0 & 1 & \\
\hline $\begin{array}{l}\text { Paraurethral } \\
\text { tear }\end{array}$ & 0 & 1 & 0 & 1 & \\
\hline PPH & 3 & 2 & 7 & 6 & \\
\hline Fever & 1 & 2 & 1 & 4 & \\
\hline \multicolumn{5}{|c|}{ Fetal complications } & \\
\hline Neonatal sepsis & 1 & 0 & 1 & 2 & \\
\hline MAS & 0 & 1 & 0 & 1 & \\
\hline $\begin{array}{l}\text { Birth } \\
\text { asphyxia }\end{array}$ & 1 & 2 & 0 & 0 & \\
\hline
\end{tabular}

\begin{tabular}{|c|c|c|c|}
\hline \multicolumn{4}{|c|}{ Apgar score at $1 \mathrm{~min}$} \\
\hline Apgar score & DH & VB & \multirow{3}{*}{$\begin{array}{l}x^{2}=0.7168 \\
d f=1 \\
p=0.39718\end{array}$} \\
\hline$\geq 7$ & $\begin{array}{l}144 \\
(80 \%)\end{array}$ & $\begin{array}{l}135 \\
(75 \%)\end{array}$ & \\
\hline$<7$ & $\begin{array}{l}36 \\
(20 \%)\end{array}$ & $\begin{array}{l}45 \\
(25 \%)\end{array}$ & \\
\hline
\end{tabular}

Apgar score at 5 minutes

\begin{tabular}{|llll|}
$\geq 7$ & 162 & 153 & $\mathrm{x}^{2}=1.429$ \\
\hline$<7$ & $(90 \%)$ & $(85 \%)$ & $\mathrm{df}=1$ \\
& 18 & 27 & $\mathrm{P}=0.285$ \\
\hline
\end{tabular}

Maternal complications were similar in both groups except few complications like transient tachycardia and dryness of mouth were slightly more in Valethamate group, but which is not statistically significant $(p=0.268)$. Fetal complications were comparable in both groups.

\section{DISCUSSION}

In the present study, the mean duration of active phase of labour in drotaverine group was $123.12( \pm 37.82)$ and $102.75( \pm 36.90) \mathrm{min}$ in primigravida and multigravida respectively whereas in Valethamate group results were $156.30( \pm 45.10)$ and $139.98( \pm 45.89) \mathrm{min}$. There was a statistically significant reduction in the duration of active phase of labor in both primigravida and multigravida given drotaverine when compared with Valethamate bromide. Drotaverine was significantly more effective than Valethamate $(p<0.0001)$. The results of another study done by Malaysarkar et al are similar showing the duration of active phase to be $174.7 \mathrm{~min}$ in primigravida and $148.2 \mathrm{~min}$ in multigravidae given drotaverine compared to $196 \mathrm{~min}$ in primigravida and $176.1 \mathrm{~min}$ in multigravida given valethamate bromide. ${ }^{11}$

Mishra et al also found duration of active phase of labor to be less in women given Drotaverine (205 min in primigravida and $105 \mathrm{~min}$ in mutigravida) compared to Valethamate bromide (275 min in primigravida and 210 min in mutigravida). Present study results were very similar with results of another study done by Jayashree et al. ${ }^{13}$ In the present study, duration of active phase of labour was less than $2 \mathrm{hrs}$ in $46.42 \%$ of primigravida and $57.35 \%$ of multigravida in drotaverine group, compared to $25.40 \%$ of primigravida and $37.93 \%$ of multigravida in Valethamate group corroborating nicely with study by Jayashree et al. ${ }^{13}$ Thirteen trials $(n=1995)$ reported on the duration of first stage of labour, which was significantly reduced by an average of 74.34 minutes when antispasmodics were administered (mean difference (MD) -74.34 minutes; 95\% confidence Interval (CI) 98.76 to -49.93$).^{14}$

Dahal $\mathrm{P}$ et al reported in their study that the mean duration of active phase of labour in group 1 (Valethamate group), 2 (Drotaverine group) was 254.29 $\pm 96.621 \mathrm{~min}, \quad 178.31 \pm 73.412 \mathrm{~min} \mathrm{~min}$ respectively. ${ }^{15}$ Average duration of active phase of labour in primigravida 186.3 minutes ( $3 \mathrm{hr} 6 \mathrm{~min}$ ) and 140.76 minutes ( 2 hour 20 minutes) in multigravidae $\mathrm{DH}$ and 254.2min (4 hour 14 minutes) and 172.82 (2 hour 52 minutes) in VB groups seen in a study done by Palii SB et al. ${ }^{16}$ In primigravida the mean duration of active phase of first stage of labor was $156.7 \mathrm{~min}$ and $110.7 \mathrm{~min}$ in valethamate group and injection drotaverine group respectively. The $\mathrm{p}$ value $=0.001$ was highly significant. In multigravidae the mean duration of active phase of first stage of labor was $126.3 \mathrm{~min}$ and $96.2 \mathrm{~min}$ in valethamate group and injection drotaverine group respectively. The $\mathrm{p}$ value $=0.001$ was highly significant in study of Changede PR. ${ }^{17}$ Sinhasane $\mathrm{H}$ et al concluded in their study that duration of active stage of labour was significantly less in drotaverine group $(3 \mathrm{hr} 50 \mathrm{~min} \pm 159$ and $2 \mathrm{hr} 29 \mathrm{~min} \pm 61.5$ in primigravida and multigravidae respectively) than valethamate group (4 hr $25 \mathrm{~min} \pm 196.5$ and $3 \mathrm{hr} 21 \mathrm{~min} \pm 111.5$ in primigravida and multigravidae respectively). ${ }^{18}$ Mishra et al found the rate of cervical 
dilatation to be $2.05 \mathrm{~cm} /$ hour in primigravida and $3.68 \mathrm{~cm} /$ hour in multigravida given drotaverine compared to $1.53 \mathrm{~cm} /$ hour in primigravida and $2 \mathrm{~cm} /$ hour in multigravida given Valethamate. Similar results were found in studies done by Rohwer C et al, Palii SB et al, Sinhasane et al, Sharma JB et al, Devinder et al and Kolhon $\mathrm{P}$ et al including the present study, where rate of cervical dilatation in drotaverine group for primigravida and multigravida were $3.0 \mathrm{~cm} / \mathrm{hr}$ and $3.5 \mathrm{~cm} / \mathrm{hr}$ respectively compared to $2.67 \mathrm{~cm} / \mathrm{hr}$ and $2.90 \mathrm{~cm} / \mathrm{hr}$ in Valethamate group and the difference is statistically significant $\mathrm{p}=<0.0001$ for both groups. ${ }^{14,16,148-21} \mathrm{Six}$ studies $(\mathrm{n}=820)$ described that administration of antispasmodics significantly increased the rate of cervical dilatation by an average of $0.61 \mathrm{~cm} /$ hour (MD 0.61 $\mathrm{cm} /$ hour; $95 \%$ CI 0.34 to 0.88$).{ }^{14}$ According to Palii SB et al cervical dilatation was $1.92 \mathrm{~cm} / \mathrm{hr}$ and $2.58 \mathrm{~cm} / \mathrm{hr}$ in primigravida and multigravidae respectively in $\mathrm{DH}$ group and $1.44 \mathrm{~cm} / \mathrm{hr}$ and $2.19 \mathrm{~cm} / \mathrm{hr}$ in VB group. ${ }^{16}$ Cervical dilatation was $3.8 \mathrm{~cm}$ and $2.68 \mathrm{~cm}$ in primi in $\mathrm{DH}$ and $\mathrm{VB}$ group and 4, $36 \mathrm{~cm}$ and 3, $3 \mathrm{~cm}$ in multi in DH and VB in a study done by Changede et al. ${ }^{17}$ Cervical dilatation were $1.83 \mathrm{~cm} \pm 1.18$ and $2.82 \mathrm{~cm} \pm 1.24$ in primigravida and multigravidae in drotaverine group and $1.58 \mathrm{~cm} \pm 1.05$ and $2.08 \mathrm{~cm} \pm 1.26$ in primigravida and multigravidae in valethamate group. ${ }^{18}$ Dilatation in primiparous drotaverine group was $2.3 \pm 0.6 \mathrm{~cm} / \mathrm{hr}$ in multigravidae $2.7 \pm 0.5 \mathrm{~cm} / \mathrm{hr}$ respectively (Efficacy of intramuscular Drotaverine use for cervical dilatation in first stage of labour. ${ }^{21}$ Injection to delivery interval was $209.80 \pm 45.13$ $\min$ and $190.92 \pm 38.96 \mathrm{~min}$ in valethamate and drotaverine group respectively. There is significant difference when two study groups were compared.

There is a strong correlation between cervical dilatation and no. of injection in a reciprocal manner (Pearson correlation coefficient; -1). Inj to delivery interval were $192.56 \mathrm{~min} \pm 75.479$ and $249.13 \mathrm{~cm} \pm 88.321$ in drotaverine and valethamate group respectively. ${ }^{15}$ In study of Sharma JB mean injection to delivery interval was $220.07 \pm 86.12$ min and $194 \pm 57.04$ min respectively. ${ }^{19}$ Mean injection to delivery interval were $183.2 \mathrm{~min}$ (SD 78.8) in the Drotaverine group compared to $206.5 \mathrm{~min}$ (SD 69.7) in the Valethamate group in study done by Madhu $\mathrm{C}$ et al. ${ }^{22}$ Maternal complications were comparable in both Drotavarine and Valethamate groups. Studies done by Devinder et al, Khosla et al, Tiwari et al and Sharma et al showed no major side effects with drotaverine and Valethamate bromide. ${ }^{20,23,24,19}$ Transient maternal tachycardia was noted in $16 \%$ of cases receiving Valethamate bromide in studies done by Khosla et al and Tewari et al, $28 \%$ of cases developed transient maternal tachycardia in study done by Devinder et al. ${ }^{23,24,20}$ Transient side effects such as foeto-maternal tachycardia, flushing of the face and dryness of mouth were noted with Valethamate. A few patients complained of headache in the Drotaverine group ${ }^{22}$. Sinhasane et al had reported dryness of mouth, palpitation and transient fetal tachycardia were more among VB group in his study. ${ }^{18}$ Dryness of mouth, flushing of face and tachycardia were more among VB group in another study. ${ }^{17}$ Total $17(4.72 \%)$ patients had atonic PPH. Out of them 7 was in Valethamate, 10 in drotaverine. In study by J.B Sharma, there was $18 \%$ incidence of PPH in drotaverine group. ${ }^{19}$ In another study had shown that total $14(4.7 \%)$ patients had atonic PPH. Out of them 5 were in Valethamate, 5 in Drotaverine..$^{15}$ Out of 360 patients, $90.56 \%$ had spontaneous vaginal delivery, $1.39 \%$ had instrumental delivery and $8.05 \%$ had LSCS. There is no significant difference between the two groups. Similar results were found in studies done by Gupta et al and Dahal $\mathrm{P}$ et al. $^{25,15}$ There was no significant difference in neonatal outcome in two groups. About $1.1 \%$ newborn suffered from suspected neonatal sepsis (2 in DH group versus 2 in VB group), $0.56 \%$ had meconium aspiration syndrome and $0.83 \%$ had birth asphyxia. They required NICU admission. There was also no statistical difference noted in the APGAR scores at 1and 5 mints.7 Dahal $\mathrm{P}$ et al reported comparable fetal outcome in DH and VB group. ${ }^{15}$ Apgar score was comparable in both $\mathrm{DH}$ and VB seen in results of Palii SB et al. ${ }^{16}$

\section{CONCLUSION}

Although both Drotaverine hydrochloride and Valethamate bromide are safe for both mother and foetus Drotaverine is more effective than Valethamate bromide in reducing the duration of labour. It has definitely proven to shorten the duration of labour and provide early relief from distress for the labouring women. Thus, we can conclude that drotaverine hydrochloride has promising beneficial effects on labour and safe to use.

Funding: No funding sources Conflict of interest: None declared

Ethical approval: The study was approved by the Institutional Ethics Committee

\section{REFERENCES}

1. Chandraharan E, Amarasinghe I. Physiopharmacology of labour. The management of labour, 2nd ed. editors Arulkumaran S, Penna LK. Orient BlackSwan/ Universities Press; 2005:1-25.

2. Caughey AB, Sundaram V, Kaimal AJ, Cheng YW, Gienger A, Little SE, et al. Maternal and neonatal outcomes of elective induction of labor. Evidence report/technology assessment. 2009;176:1.

3. Dencker A, Berg M, Bergvist L, Ladfors L, Thorsen LS, Lilja H. Early versus delayed oxytocin augmentation in nulliparous women with prolonged labour - a randomized controlled trial. Br J Obstet Gynaecol. 2009;116:530-6.

4. Neilson JP, Lavender T, Quenby S, Wray S. Obstructed labour. British Med Bull. 2003;67:191204.

5. Himangi S, Anahita R, Vanita S, Kumud M. The efficacy of Camylofin dihydrochloride in acceleration of labour. A randomized double-blind trial. J Bombey Hosp. 2004;45(3):1. 
6. Singh KC, Jain P, Goel N, Saxena A. Drotaverine hydrochloride for augmentation of labour. Int $\mathrm{J}$ Gynaecol Obstet. 2004;84:17-22.

7. Hudecek R, Nagy J, Unzeeitig V. The effect of spasmolytics on dilatation of the uterine cervix. Ceska Gynaecol. 1997;62:11-4.

8. Lowe NK. The nature of labour pain. Am J Obstet Gynecol. 2002; 186(5):16-24.

9. Rao KB. Prolonged and obstructed labour. In: Arulkumaran S, Penna LK, Rao KB editors. The management of labour. $2^{\text {nd }}$ edition, India: Orient Longman Private Ltd; 2005:340-349.

10. Driscoll OK, Sronge JM, Minogue M. Active management of labour. Br Med J .1973;3:135-7.

11. Sarkar M, Goswamy BL. A study of drotaverine on duration on 1st stage of labor. J Int Med Sci Acad. 2000;13(4):256-7.

12. Mishra SL, Toshiwani A, Banerjee R. Effect of drotaverine on cervical dilatation- a comparative study with Epidosin (Valethamate bromide). J Obstet Gynecol India. 2002;52(3):76-9.

13. Jayashree S, Jammanavar JA, Sujatha MS, Comparison of Drotaverine and Valethamate bromide in first stage of labor. Int J Biol Med Res. 2013;4(2):3215-8.

14. Rohwer AC1, Khondowe O, Young T. Antispasmodics for labour. Cochrane Database Syst Rev. 2013 ;(6):CD009243.

15. Dahal P, Banerjee B, Uprety DK, Das BP, Thakur A, Agrawal A. Comparative study of efficacy of drotaverine hydrochloride and Valethamate bromide with control in first stage of labour. Health Renaissance. 2013;11(1);38-42.

16. Palii SB, Akkupalli VL, Maddi S. The comparative study of Drotaverine hydrochloride and Valethamate bromide in first stage of labour. J South Asian Fedaration Obstet Gynaecol. 2013;5(2);52-6.

17. Changede PR. Comparison of injection drotaverine and injection Valethamate bromide on duration and course of labor. Int J Reprod Contracept Obstet Gynecol. 2016;5(6):1836-42.

18. Sinhasane H, Nishty GM. A comparative study on the efficacy of drotaverine and Valethamate on cervical dilatation during labour. Int $\mathbf{J}$ Reprod Contracept Obstet Gynecol. 2017;6:423-6.

19. Sharma JB, Pundir PK, Murthy NS, Drotaverine HCL Vs Valethamate bromide in acceleration of labor, Int J Gynecol Obstet. 2001;74:255-60.

20. Devinder K, Ravinder K. Comparison of Drotaverine and Epidosin in first stage of labor. J Obstet Gynecol India. 2003;53(5):449-52.

21. Kalhon P, Patil AB, Patel R. Efficacy of intramuscular Drotaverine use for cervical dilatation in first stage of labour. Int $\mathbf{J}$ Sci Tech. 2015;14(3):670-4.

22. Madhu C, Mahavarkar S, Bhave S. A randomized controlled study comparing Drotaverine hydrochloride and Valethamate bromide in the augmentation of labour. Arch Gynecol Obstet. 2010;282(1):11-5.

23. Khosla AH, Bala I, Dahiya K, Sangwan K. A comparative study of the efficacy of Valethamate bromide with drotaverine in normal labor. J Obstet Gynecol India. 2003;53(6):568-70.

24. Tewari K, Jabeen R, Sabzposh NA, Rabbani T. Comparison of Hyoscine butyl bromide and valethamate bromide in shortening the duration of labour. Indian Medical Gazette. 2003;137(1):15-9.

25. Gupta K, Mukharjee K, Chowdhary B. Effect of Drotaverine on the first stage of labour. Obstet Gynae Today. 2003;8(3):210-5.

Cite this article as: Mandal AK, Molla N.

Comparison of efficacy of Drotaverine hydrochloride and Valethamate bromide in the augmentation of labour: a hospital based randomized trial. Int J Reprod Contracept Obstet Gynecol 2018;7:1579-85. 